for blood samples. Tissue banks may be used for late-onset diseases. The process is based on informed consent, and there is total confidentiality, says Stefansson.

Although deCODE is a private company, the Icelandic government is a great supporter, says Stefansson, and is in favor of the Roche deal. According to Elizabeth Silverman, gov- ernments in Scandinavian countries, especially Finland, have been under siege from genomics companies looking to secure material for genetic exploration. deCODE and its deals are seen by the government as a mechanism of ensuring that the Icelandic population retains some of the benefits. As well as the trickle-down to the medical research commu- nity from deCODE, there are other direct benefits. Roche has agreed to provide any medicines arising from resulting discoveries to the Icelandic people free of charge. "It was originally my suggestion," says Stefansson. "It's a symbolic gesture [of thanks] for the contribution of the patients participating."

Emma Dorey

\title{
German companies undecided on flotation venue
}

The number of German biotechnology companies with publicly traded shares could reach double figures by the year 2000, but it is far from clear where the companies are likely to float. At present, Germany's only public biotechnology company is the laboratory supplier, Qiagen (registered in Venlo, The Netherlands), which floated on Nasdaq but which is now also quoted on Frankfurt's junior stock exchange, the 'Neue Markt'. However, according to Thomas Gutschlag of financial consultants, Going Public Beratung (Leonberg), "some 10 private biotech companies in Germany are candidates for initial public offerings [IPOs] before the next millennium." The companies nearest to IPOs include Morphosys (Munich), Evotec (Hamburg), and Sequenom (San Diego, CA, and Hamburg) as well as the supplier MWG-Biotech (Ebersberg, near Munich).

Gutschlag, formerly the director of the Deutsche Börse (Frankfurt) and the man responsible for conceiving and launching the Neue
Tony Schuh believes European investors may be more generous than US investors.
However, the biotechnology start-up companies themselves remain cautious about the Neue Markt option. Jörn Aldag, the finance director of drug screening specialist Evotec Biosystems, which is looking to go public early in 1999, is concerned that stock prices are unduly driven by investor sentiment. "Stock gamblers affect the IPOs at the Neue Markt," he says. The market is certainly highly volatile with many stock prices doubling or halving within $24 \mathrm{~h}$.

Thomas Gutschlag admits the enormous investor demand for biotechnology and the concomitant high initial price of biotechnology IPOs could be a problem for flotations in Germany. He thinks that initial stock prices will exceedby at least one third or halfvaluations that were based on DAX $100 \quad$ companies (Germany's 100 biggest companies). The more overpriced the stock, the more likely the prices will drop, and that could have repercussions for future money raising. "It would be very difficult to recover standing in order to at least some of the high profile offerings will occur on the German stock exchange. The market for IPOs is growing, says Gutschlag. The management of start-up companies, which used to have to run after investment bankers, now are swamped with offers, he says.

There is certainly prolific investor enthusiasm both for biotechnology and for the Neue Markt. "The demand for biotechnology shares runs to some hundred million DM in Germany," says Andreas Bremer, fund manager of BB Biotech (Schaffhausen, Switzerland). This is helped by the spectacular performance of shares on the Neue Markt: The 17 shares on it have, on average, doubled their value since listing.

Ingeborg Fürst is a freelance writer working in Munich. successfully raise money through future offerings," says Gutschlag.

"We believe there will be support for biotechnology companies listed on the Neue Markt," says Simon Moroney, CEO of, a combinatorial biology drug-discovery company. Much of that support will come from German investors who tend to invest, or can only invest, in local stocks, he says. Morphosys plans a listing in late 1998 and could thereby become the first "genuine German biotechnology company" to go public.

Toni Schuh, managing director of Sequenom, believes that European investors may, in some respects, be more generous to new companies than investors in the United States. While experienced US West Coast venture capitalists may focus on the bottom line, he says, European investors look for different qualities. They may be willing to invest in a broader range of tech- nologies or they may plan to hold stock for longer, says Schuh.

The novelty value of both biotechnology and the Neue Markt would make any biotechnology company quoted there much more highly visible than it might be on Nasdaq where hundreds of biotechnology stocks are traded. However, that is not necessarily a good thing. Its underwriters took the Danish biotechnology company NeuroSearch (Copenhagen) public on the Copenhagen stock exchange, and its shares have soared there. However, a second planned NeuroSearch offering on Nasdaq hasn't happened so far. One reason, probably, is that Danish investor enthusiasm has driven the stock far above comparable US valuations.

The "Neurosearch phenomenon" robs companies of the opportunity to raise money in a much bigger money market. "Nasdaq has listed most of the companies; it offers most of the investors and most of the money," says Toni Schuh. "Those who wish to sell a painting by Van Gogh should go to Sotheby's, not a flea-market." From its inception, Sequenom has had both German and US offices, something that could be useful in furthering transatlantic investor relations. Sequenom will decide toward the end of 1998 whether to float or seek further private funding. Both Evotec and Morphosys are considering opening US operations, although they say this is unconnected with any plans for Nasdaq flotations.

EASDAQ (Brussels), the European electronic exchange, is another potential flotation venue but not one that finds much favor with German companies. Simon Moroney appreciates the fact that "EASDAQ attracts money from all over Europe," but he considers that the national investment traditions may still mean that most of the money will continue to be available through national markets. Dual listings-Nasdaq plus EASDAQ or a European national exchange-imply higher costs and effort. In turbulent financial times, one attraction of Nasdaq over other exchanges is the simple fact that offerings by non-US companies can be withdrawn without any public announcement, leaving a company's image largely untarnished with investors.

Ingerborg Fürst 